\title{
Modeling of the Human Needs: an Economic Interpretation of Maslow's Theory of Motivation
}

\author{
DIANA GENKOVA \\ Department of Marketing and Strategic Planning \\ University of National and World Economy \\ 1700 Sofia, Student Town "Hr. Botev" \\ BULGARIA
}

\begin{abstract}
In this article, we examine the macroeconomic parameter final consumption (FC) by assuming it is an indicator of human development; the latter, ultimately, determines the socioeconomic conditions in society. The aim is to bind the aggregate final consumption to human needs. For this purpose, the methodology of the analysis grows up on two pillars: on the side of human needs we take Maslow's theory of motivation, and on the side of the economy, we take the product structure of total final consumption. By analogy, based on a theoretical analysis, we constructed a model, which describes the basic human needs classified by Maslow [1], in economic terms. We tested empirically the model, especially, the hierarchy of the five product categories of FC referred to basic human needs. Other hypotheses about relationships between this product structure of FC and the socio- economic standard are also under consideration.
\end{abstract}

Key-Words: - motivation theory, consumer behavior, society, final consumption, human development, socio-economic standards.

Received: May 31, 2020. Revised: December 2, 2020. Accepted: January 3, 2021. Published: January 14,2021

\section{Introduction}

A range of factors complicated in interacting each other drives society. Historically, it was proven they differ in nature - from demographic to social, economic, political, and ethno-cultural, etc. [36], [2]. In time, societies (countries) differentiated from one another in certain factors [6], [23]. Despite the theoretical assumptions and actions directed at the cohesion (through the process of international political integration, for example), it is a common practice, some of these forces to increase additionally differences between countries. Specifically, from a certain point in time, the institutional structure of society became a key factor of differences between societies in terms of economic progress and living standards [6].

Economic behavior and economic performance of society are a synthesis; they are product of a complex system of processes and phenomena. In other perspective, they can be seen as a driver of social dynamics and progress. In other words, in a given period, the economic performance of a society plays both - the role of a consequence but also of a driver for social changes. In the role of a consequence, the economic performance manifests the efficacy of an institutional structure.

Final consumption (FC) of society is one of the basic parameters of their economic achievements; as known, it is also a major component of gross domestic product (GDP), calculated by the methodology of final use [35]. In essence, final consumption is a process of using goods and services that directly results in meeting human needs - individual or / and collective as well [39].

\section{Methodological issues}

The subject of analysis is to bind FC to human needs; the letter is an indicator of human development. To this end, I take the classification made by A.H. Maslow in their theory of motivation on the bases of the significance of needs for human 
behavior [1]. The aim is to construct a model for describing the human needs and human development in economic terms. My approach differs from previous attempts to present Maslow's theory of motivation in economic terms.

The other studies in this field mainly stem from individual consumer behavior. Specifically, this is the case of a new approach in economic theory triggered by a sequence of authors like Simon [15], Katona [11], Winter [34], Shackle [13], Leibenstein [14], March [16], Elster [17], Boland [21], Heiner [29], Earl [26], who strived to provide the fundamentals of an alternative viewpoint towards rational consumer. In contrast to the Neoclassical economics - which argues that rational consumer is psychologically neutral, mainly in the writings of Pareto [41], Robbins [22], Friedman [24], and Samuelson [27] - the new approach introduced the idea of possible psychological bases of the consumer behavior. In this way, a trend towards "de-neutralization" of the theory of rational consumer was started [7]. Seeley, who tried to integrate Maslow's concepts about general human behavior with the framework developed by economists to explain consumer behavior [10], provided another attempt upon this approach.

We argue consumer behavior is a complex process driven by a variety of determinants - some of which mental and physiological by nature, but there are sociological and economic as well. In this analysis, we strive to transform Maslow's theory of motivation into economic effects. To this end, here we stand at the position of society, by putting into consideration consumer behavior of the community at large. The methodology of the analysis is based on the system approach and system analysis in economics. The latter achieved by the input-output method, allows identifying products as the output of economic activities. Individual products can be used in different ways, including for final consumption.

Taking the products used for FC at the community level allows us to clearly distinguishing the economic aspect from mental and sociological ones of human behavior. Binding FC to human needs will allow us to consider empirically the relationship between these aspects, but also to evaluate the aggregate effect of consumer behavior of individuals, who seek to satisfy their needs and wants.

We assume FC is not only an economic indicator but also a social one, reflecting human development. One of its advantages - it is a strong measurement, which assesses the set of products directly used to serve human needs, either individual or collective. Another one advantage, it comprises all final consumption expenditures paid for by the community at large - including by households, as well as by governments and non-profit organizations [35].

\section{Research methodology}

To develop the model, I conducted a two-stage analysis. First, goods and services used for FC and statistically described in the use table ${ }^{\mathrm{i}}$, were grouped into five categories, by analogy with the classification of basic human needs in Maslow's theory of motivation [1]. Next, I carried out an empirical research based on a sample of 25 European countries to test the model, specifically, the hierarchy of the product groups.

Several hypotheses were tested. First, there is a hierarchy in the 5-category-product model of total $\mathrm{FC}^{\mathrm{ii}}$ analogously to the hierarchy identified by Maslow in the system of basic human needs. Second, countries (societies) differ significantly from each other in terms of this 5-category-product model of FC. Third, the more significant the differences between economic standards of countries, the greater the differences between countries in the 5-category-product model will be. Fourth, less developed countries have a larger product category, which corresponds to the prime (physiological) needs, than developed ones; and this follows from Maslow's assumption about prime needs is the highest priority of human behavior [1]. Fifth, more developed countries will have higher stages of FC product pyramid.

A variety of factors influence total $\mathrm{FC}$, among them mental, ethno-cultural, demographic, religious, geographical, socio-economic, political, etc. Therefore, the 5-category-product model of FC will manifest common regularities but also the specific traits of any community (individual country) as well. Countries differ from each other not only in economic standards, but also in their socio-political pattern. Acemoglu and Robinson claimed a positive correlation between economic and social standards [6]. If empirical tests confirm my hypotheses especially, 2, 3 and 4 - this model of FC can be used as informative on human development in socioeconomic terms, especially, in comparative analysis.

\subsection{The theoretical model: from Maslow's theory of motivation towards FC}

\footnotetext{
${ }^{\mathrm{i}}$ It is an integral part of the National Accounts.

ii As mentioned above, total FC comprises three groups of expenditures: by households, by government and by nonprofit organizations, serving households [35].
} 
Stemming from distinct starting points, we can present FC in different perspectives; therefore, we can get a variety of descriptions. We may come out of production methods, or product typology, or consumer behavior (market segments), the ways in which consumers get products (on the market, by manufacturing on their own, or by donations of state or private organizations), etc. Each of these perspectives provides us with specific information. The perspective that describes FC product diversification $^{\mathrm{iii}}$ is a good starting point to present the five categories of basic human needs in economic terms. However, one more step becomes necessary to move from production to "methods" of using products in satisfying human needs. ${ }^{\text {iv }}$

Using of products for FC is activity of socialdemographic nature. Unlike economic ones, in socio-demographic activities it is not easy, nor always possible to evaluate the transformation of inputs into outputs. According to Matveev, in processes of psychological and sociological nature, there is no energetic equivalence between outputs and inputs [9]. Objective determinants of consumer value are affected by subjectively acting consumer perceptions; the latter limit the outcome of a consumption process [38]. In this sense, the outcome of final consumption is strongly the result of a complex mechanism, which comprises a variety of factors of human behavior. Maslow emphasized explicitly, basic needs are a key determinant of human behavior, but they are not the only one [1].

To link human needs to economic behavior of the community at large, I classified technologically identified products used for FC into five categories. To this end, I conducted a theoretical analysis to define product categories, which to correspond to the categories of basic needs. I used deduction and method of analogy, seeking to draw out the contact point between the two sides of the consumption process, but also to keep in mind the specificity of each of them. The output of this analysis is presented in Table 1 (in the appendix).

\subsection{Constraints and theoretical assumptions}

I identified several constraints and made some basic assumptions.

First, to test the model empirically, I work with data from the use table. Using aggregate data on the

\footnotetext{
iii According to production methods described in the Central Product Classification (CPC) [3], [4].

iv This is FC itself; the other ways of using goods and services (products produced) are intermediate consumption, capital formation, and exports [35]. The four ways serve different types of societal needs [39].
}

consumption raises further questions to the attempt to describe human needs in economic terms [33], [43]. Especially, in the light of marketing theory, it seems to be compromised the idea of describing Maslow's pyramid at the community level. But is that really the case?

In an aggregate description, the information on market segments and specific features of products purchased is hidden, but not lost. This kind of information will be relevant to my study if we assume the hierarchy of needs correlates significantly to market segmentation and product modification in product classes ${ }^{v}$. Should we accept this assumption?

Market segmentation (in case of products for FC) becomes possible under specific conditions, when some specific demand and wants of a group of customers appear unsatisfied by the active market offers. This may be due to the emergence of the respective need at a new higher level in quality terms $[40]^{\mathrm{vi}}$. At the new stage, requirements for additional product characteristics and distribution services appear, some of them may relate to the "representativeness" of the consumption process ${ }^{\text {vii. }}$. We can attribute representativeness through consumption to "esteem" needs. Going back to market segments, this phenomenon usually takes place though product modification or even may require a new product to be developed ${ }^{\text {viii. However, }}$ this qualitative transition in market terms does not change the essence of the initial human need. Even though the way of serving a basic human need changes, the nature of the need is preserved. In marketing theory, this objective fact often is overlooked. What changes is the degree of satisfaction, which from a certain moment allows another need to arise. The need for food or clothing is especially indicative in this respect.

Purchasing a pair of trendy shoes from a boutique or from an online store adds benefits; in these cases, consumer value will be greater than purchasing from a conventional outlet. In the first case, customers may benefit from demonstrating "belongingness" to the group of wealthy shoppers who wear branded clothing, shoes, and accessories;

\footnotetext{
${ }^{\vee}$ A product class has a specific code in the CPC.

${ }^{v i}$ Manov called this hypothesis the second regularity in the development of human needs.

vii Representativeness and personal graded status can be achieved not only through consumption, but also through personal contribution to social progress as well [9], [25]. viii It may belong to other product class of the CPC. Manov called this phenomenon the first regularity in the development of human needs [40].
} 
in the second case, additional benefits may be seen in time saving, belongingness to innovators, etc. However, in all the three cases, the core subject of purchases relates to a particular basic human need, which can be satisfied, only if we have at a disposal a pair of shoes, no matter the manner we get it or the specific characteristics of design. In other words, in regards with the need for clothing and shoes (a physiological), on the side of the needs we stand at the same stage of Maslow's pyramid, whereas on the side of the product structure of FC changing socioeconomic conditions make us pass to a higher stage.

Market segmentation is a manifestation of improvements of socio-economic conditions. At an individual level, a need previously met to a sufficient degree, at a later moment may appear on a new qualitatively higher level or allow the emergence of new needs [40]. At the community level, the aggregate effect of all these may involves consumption increases in products of the same class (due to the emergence of new market segments), but also increases in the consumption of other product classes (due to the development of new products). No matter the result, the consumption process does not change the essence of a basic human need; it can make new needs to arise. Some of the new products required may fall into categories from higher stages of our 5-category model of FC.

Second, the product structure of FC here is expressed in expenditures paid for by three categories of economic agents [5]. Governmental units and non-profit organizations play mainly a supportive role, being mediators for producers and consumers in meeting individual and collective human needs. Their portion in FC largely depends on the degree of social integration, political rights and economic standards achieved in a given society. In this sense, total FC could serve better to measure the economic performance in serving human needs, as it comprises not only the individual but also collective efforts directed to this end. Assessments of total FC comprises volumes in kind, price levels, and product modification by market segments. It is worth emphasizing, as a macroeconomic parameter total FC reflects the socio-economic standard by country. Therefore, the 5-category-product model developed on this basis can express not only the relationship between the categories of basic human needs, but also the specific socio-economic and political circumstances of a society, in a given time period.

Third, according to Maslow's theory, the five categories of basic human needs appear in a hierarchy. Maslow explicitly emphasized that a category of needs and the associated behavior can serve as a channel for the emergence of other types of needs [1]. The hierarchy is manifested in two aspects. First, the emergence of a new need, which usually rests on the satisfaction to a sufficient degree of another stronger and, therefore, earlier need. The other one, the degree of satisfaction, at which a new need(s) could arise, is different for distinct needs. In principle, at the higher stages, needs have a relatively lower intensity of satisfaction, while the needs at the lower stages have a higher intensity of satisfaction [1]. Going back to $\mathrm{FC}$, we can expect this hierarchy to appear in the corresponding product categories.

Fourth, to test empirically the relationship between product categories, I chose to analyze a period. This allows me to consider the changes in the conditions of the consumption process.

\section{Testing empirically the model}

To test the model, I conducted empirical analysis on a sample of 25 European countries. I used data from the use table available for as many of the recent years as possible at the time of the analysis. Selected in this way, surveyed period is 2000-2010.

\subsection{Testing of product categories hierarchy}

The results of empirical analysis confirm my first hypothesis. There is a hierarchy of the five product categories of total FC. It is identified in the pattern of any individual country and for the sample as well. The common pattern is shown in Fig.1. It takes pyramid form, demonstrating the 5-categoryproduct structure of FC for 2000, 2005 and 2010. Even marginally, the diagram figures out changes in the proportion of product categories by year. I constructed the pyramid by using the cumulative relative shares of product categories. Relative shares of product categories for the sample are weighted mean of countries' product shares and countries' population. Here, the proportion of the five product categories presents the model; therefore, the total sum is $100 \%$. The pyramids for the three observed years are similar, with minimal differences in the proportion. No matter marginal, changes confirm the hierarchy in dynamics.

The bottom stage represents the category of products for physiological needs; it is the largest one. Over the period, although modestly, it decreases starting at $44.67 \%$ in 2000 and ending at $43.54 \%$ in 2010 . Moving up to the next stage, which represents the category of safety and security products (here, perceived mainly in political and socio-economic terms), this category has the second 
largest portion. Although slightly noticeable in Fig. 1 , over time the share of this category increased, starting from $29.94 \%$ in 2000 , to $31.17 \%$ in 2005 and ending at $32.3 \%$ in 2010.

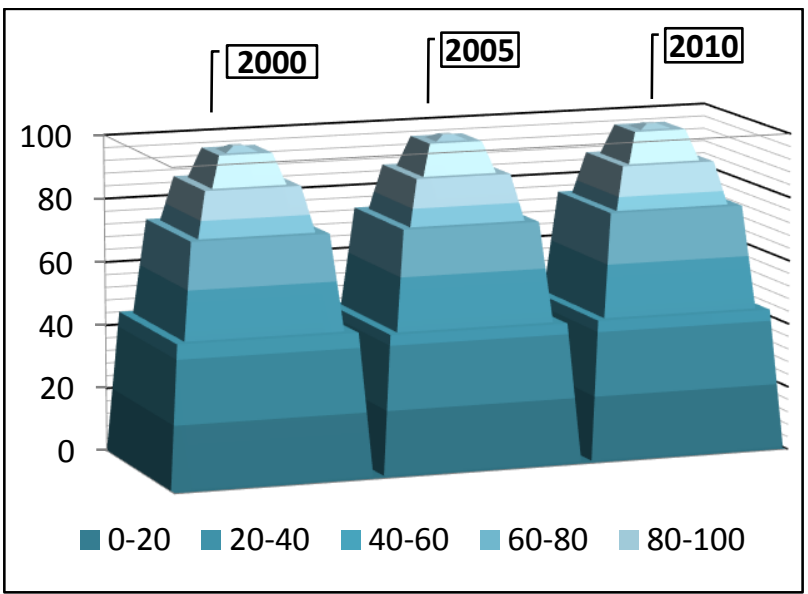

Figure 1: The empirical 5-category-product model of final consumption (the sample at large).

Moving one-step up, we come to the stage of "connectivity" product category. In the three observed years, respectively, it accounts for $14.14 \%$, $14.32 \%$ and $13.33 \%$, demonstrating the third largest portion of total FC. During the crisis years of 20082010, it showed some instability. Moving one-step up, we come to the stage of "recreation and culture" product category. Over the period, it accounts for $9.57 \%, 9.65 \%$ and $9.51 \%$ of total FC for observed years. The figures spell out a decreasing role of the category during the world economic crisis and this fully corresponds to the hypothesis about the hierarchy of FC 5-product categories.

The upper stage of the pyramid represents "selfactualization" category, perceived in a very special sense (see table 1 in the appendix). This category has the smallest stage, almost invisible on the diagram. It accounts for less than $2 \%$ of total FC, varying from $1.68 \%$ in 2000 to $1.32 \%$ in 2010 . Over time, its relative share decreased, especially in crisis years, mainly due to in many countries a reduction in spending on research and development paid for by the community at large took place.

As mentioned earlier, the hierarchy is identified at the country level too. The 5-category-product structure of FC takes the form of pyramid for each of the 25 examined countries. Here, to save space, I show the pattern of only four countries, which represent four levels of economic standards. ${ }^{\text {ix }}$

ix The four groups of countries differ from each other in GDP per capita in PPP (EU28 = 100). This classification is widely applied for the purposes of the EU cohesion policy [8], [5]. First group is with (GDP per cap $<75$
However, this time I constructed the model in volume per capita; in this way, the difference between countries in socio-economic standard can be identified. This is shown in Fig.2, Fig. 3 and Fig.4, presenting the case of Estonia, Greece, Germany and Ireland for three observed years.

To construct the pyramid, I used the cumulative volume per capita of product categories. Unlike the diagram in Fig. 1, in Figs.2-4, the total sum is in value terms. For a particular year, the pyramids of countries differ from each other as each of them corresponds to a specific economic standard. The diagrams for the three observed years clearly identify differences between countries not only in the 5-category structure of FC, but also in the economic standards of FC per capita. These findings mainly confirm my second and fifth hypotheses.

The volume per capita of each of the five categories varies by country. Moreover, countries with relatively lower GDP per capita have smaller total FC and visibly different product structure, with upper stages being significantly thinner and even hardly noticeable on the diagram. In later years, the upper stages grew mainly at the expense of stage 1 , observed in all countries, although the increase in the higher categories, respectively, the decrease in the lowest have different margins by country. The differences in changes may be due to social and mental factors of consumer behavior, but also to economic and technological factors on the side of the production and distribution.

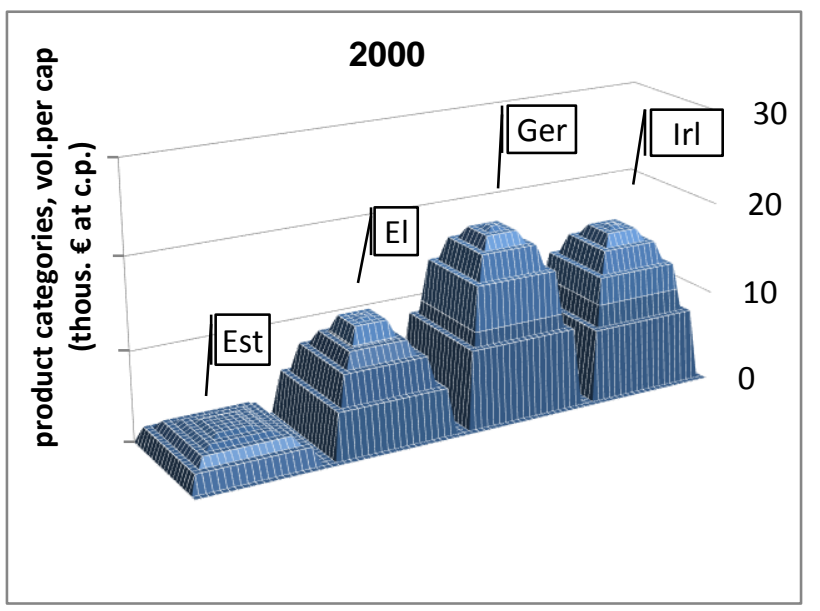

Note: Own work. Based on data of the use table [44].

Legend: Est - Estonia; El - Greece; Ger Germany; Irl - Ireland.

Figure 2. The 5-category-product model of FC by country, 2000.

percentage of the EU average); second (75 < GDP p.c. < $100)$; third (100 < GDP p.c. < 125), fourth (GDP p.c. > 125). 


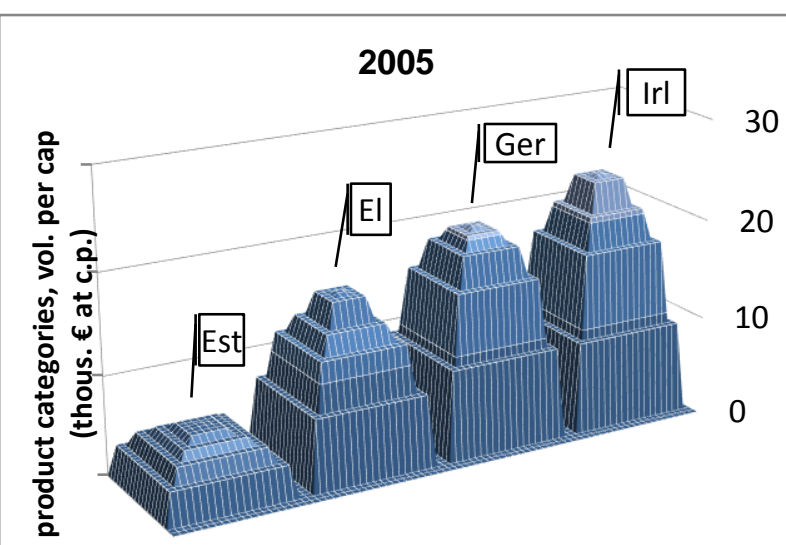

Figure 3. The 5-category-product model of FC by country, 2005.

What can the construction of Figures 2-4 tell us in addition? The height of a pyramid stage is indicative for the weight of the corresponding product category. The hierarchy of product categories is visible, as to move to a higher stage, a smaller step should be taken every time. However, the height of single stages varies from country to country.

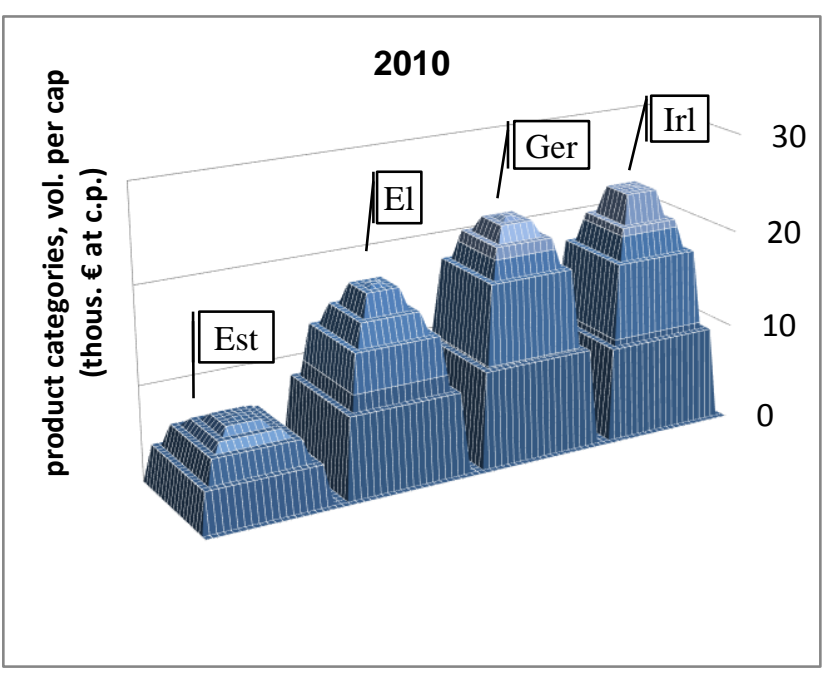

Figure 4. The 5-category-product model of FC by country, 2010.

The height of the pyramid in this version of model construction is indicative of the standard of consumption (per capita) in quantitative terms, while the construction of the pyramid (jagged part) is indicative of the standard of consumption in qualitative terms. In other words, this version is informative of differences in socio-economic conditions for human development by country. The pyramids of countries with a relatively lower economic standard are lower but also less jagged at the upper stages. It is most evident of Estonia, which was under the priority subject of the EU cohesion policy over the 2000-2010 period [8], with a GDP per capita index of $41.4 \%$ in 2000 . In turn, the pyramids of countries with a higher socioeconomic standard look clearly jagged in the upper stages, except for the last one. This finding confirms my second, fourth and fifth hypotheses.

\subsection{Other results and discussion}

To measure the difference between countries in terms of the 5-category-product structure of FC, I used an integral coefficient of structural difference [20]. It is calculated by formula (1).

$$
K s d=\sqrt{\frac{\sum_{i}^{5}\left(V_{i, j}-V_{i, 0}\right)^{2}}{\sum_{i}^{5} V_{i, j}^{2}+\sum_{i}^{5} V_{i, 0}^{2}}}
$$

where: $K s d$ is the integral coefficient of structural differences; $i$ denotes an element of the surveyed nomenclature, in our case, " $i$ " is a product category of FC; therefore, $i$ ranges from 1 to $5 ; V_{i, j}$ denotes the relative share of an $i$-th product category of FC to country $j ; j$ ranges from 1 to $25 ; V_{i, 0}$ denotes the relative share of the $i$-th product category of FC that is used in the basis country of the comparison.

For the 2000-2010 period, the difference is about $10 \%$ measured by the arithmetic mean of the integral coefficient calculated by comparing countries' product structure with that of the sample. It also turns out that the difference in FC 5-category structure correlates positively with the difference between countries in the socio-economic standard. I assessed this correlation. For this purpose, I took the GDP per capita (PPP) index as a measure of a country's socio-economic standard. To measure the difference between countries in the FC 5-category structure, I adopted a real referent structure of final consumption - one that corresponds to a high economic, social and political standard. The pattern of the Netherlands derived from the empirical analysis proved a good referent structure of FC. It is selected on the bases of a set of criteria, among them reality, high economic standard and quality of life. For the three observed years, I calculated two assessments of the correlation - one based on Spearman's rank correlation coefficient and another one based on Pearson's correlation coefficient. The results of t-tests are presented in Tab. 2 and Tab. 3.

The results of the analysis figure out, there is a statistically significant, moderate to strong negative correlation between the GDP per capita index and the distance to the Dutch 5-category product pattern 
of FC. With a risk below 1\% (with 23 degree of freedom, $\alpha=0.001$ in the case of Spearman's coefficient and $\alpha=0.005$ in the case of Pearson's coefficient), the result of the t-test is highly significant, leading to the rejection of null hypothesis (see tabl.2 and tabl.3).

Table 2: Spearman's rank correlation coefficient.

\begin{tabular}{|l|l|l|l|}
\hline \multicolumn{1}{|c|}{ Years } & \multicolumn{1}{|c|}{2000} & 2005 & 2010 \\
\hline $\begin{array}{l}\text { Spearman's rank correlation } \\
\text { coefficient }\end{array}$ & $-0,67478$ & $-0,83043$ & $-0,89174$ \\
\hline $\begin{array}{l}\mathrm{t} \text {-theoretical } \\
\text { with }(n-2)=23 \\
\text { degree of freedom (df) and } \\
\alpha=0,001\end{array}$ & $-3,505$ & $-3,505$ & $-3,505$ \\
\hline $\mathrm{t}$-statistics & $-4,289$ & $-6,992$ & $-9,242$ \\
\hline $\mathrm{t}_{\text {(statist }}<\mathrm{t}_{\text {(theor) }}$ & $\begin{array}{l}H_{0} \\
\text { rejected }\end{array}$ & $\begin{array}{l}H_{0} \\
\text { rejected }\end{array}$ & $\begin{array}{l}H_{0} \\
\text { rejected }\end{array}$ \\
\hline
\end{tabular}

Table 3. Pearson's correlation coefficient.

\begin{tabular}{|l|l|l|l|}
\hline \multicolumn{1}{|c|}{ Years } & \multicolumn{1}{|c|}{2000} & \multicolumn{1}{c|}{2005} & \multicolumn{1}{|c|}{2010} \\
\hline $\begin{array}{l}\text { Pearson's correlation } \\
\text { coefficient } \\
\text { (x average }=100, \text { GDP per } \\
\text { cap in PPP=EU28) }\end{array}$ & $-0,5854$ & $-0,7070$ & $-0,6929$ \\
\hline $\begin{array}{l}\mathrm{t} \text {-theoretical } \\
\text { with }(n-2)=23 \\
\mathrm{df} \text { and } \alpha=0,005\end{array}$ & $-2,81$ & $-2,81$ & $-2,81$ \\
\hline $\mathrm{t}$-statistics & $-3,39$ & $-4,69$ & $-4,51$ \\
\hline $\mathrm{t}_{\text {(statist }}<\mathrm{t}_{\text {(theor })}$ & $\begin{array}{l}H_{0} \\
\text { rejected }\end{array}$ & $\begin{array}{l}H_{0} \\
\text { rejected }\end{array}$ & $\begin{array}{l}H_{0} \\
\text { rejected }\end{array}$ \\
\hline $\begin{array}{l}\text { Pearson's correlation } \\
\text { coefficient } \\
(x \text { average is the weighted } \\
\text { mean of the sample })\end{array}$ & $-0,5578$ & $-0,7100$ & $-0,6958$ \\
\hline $\begin{array}{l}\mathrm{t} \text {-theoretical } \\
\text { with }(n-2)=22 \\
\mathrm{df} \text { and } \alpha=0,005\end{array}$ & $-2,82$ & $-2,82$ & $-2,82$ \\
\hline $\mathrm{t}$-statistics & $-3,15$ & $-4,73$ & $-4,54$ \\
\hline $\mathrm{t}_{\text {(statist })}<\mathrm{t}_{\text {(theor })}$ & $\begin{array}{l}H_{0} \\
\text { rejected }\end{array}$ & $\begin{array}{l}H_{0} \\
\text { rejected }\end{array}$ & $\begin{array}{l}H_{0} \\
\text { rejected }\end{array}$ \\
\hline
\end{tabular}

For the three observed years, in both approaches, t-statistics are greater than critical values. Then, that the lower the socio-economic standard, the higher the distance to the "ideal" 5-category-product structure of FC. Conversely, more developed countries have a closer FC 5-category structure to the referent one. In addition, it is worth emphasizing, the null hypothesis is rejected in each of the two approaches I used to calculate Pearson's coefficient (see tabl.3). ${ }^{\mathrm{x}}$ Thus, my second and third hypothesis are confirmed.

To test my fourth hypothesis, I assessed the correlation between countries' socio-economic standard and weights of product categories in

\footnotetext{
${ }^{x}$ Using, in the first, the average GDP p.c. of the EU, and in the second, the weighted mean of GDP p.c. of the sample.
}

countries' FC pattern. For this purpose, I calculate Pearson's coefficient by using the GDP p.c. again ${ }^{\mathrm{xi}}$ and the relative shares of the categories. The results are presented in Tab.4 and Tab.5.

Values of t-statistics spell out a significance of tested relationships in the case of only two of the five product categories (namely, 1 and 2), with 23 degree of freedom and $\alpha=0.005$. A moderately strong negative correlation proved between socioeconomic standard and the relative share of "physiological products" category. The null hypothesis rejected for each of the three observed years, since the absolute $\mathrm{t}$-statistics are greater than critical values $\left(\mathrm{t}_{1}=|-4.31| ;|-3.90| ;|-3.72|>2.81\right)$. This could be interpreted thus, the lower the economic standard, the higher the weight of "physiological products".

As to the category of "safety products", the correlation proved moderately strong and positive, since $\mathrm{t}_{2}=3.82 ; 5.14 ; 4.56>2.81$. This means, the higher the socio-economic standard the higher the weight of security products would be.

Table 4: Test of the correlation between socioeconomic standard and product categories weights.

\begin{tabular}{|c|c|c|c|}
\hline Years & 2000 & 2005 & 2010 \\
\hline $\begin{array}{l}\text { t-theoretical with }(n-2)= \\
23 \text { df and } \alpha=0,005\end{array}$ & 2,81 & 2,81 & 2,81 \\
\hline $\begin{array}{l}\text { Pearson's correlation } \\
\text { coefficient referred to } \\
\text { category } 1\end{array}$ & $-0,6687$ & $-0,6312$ & $-0,6127$ \\
\hline t-statistics $\left(\mathrm{t}_{1}\right)$ & $-4,31$ & $-3,90$ & $-3,72$ \\
\hline$H_{0}$ & rejected & rejected & rejected \\
\hline $\begin{array}{l}\text { Pearson's correlation } \\
\text { coefficient referred to } \\
\text { category } 2\end{array}$ & 0,6231 & 0,7309 & 0,6887 \\
\hline t-statistics $\left(\mathrm{t}_{2}\right)$ & 3,82 & 5,14 & 4,56 \\
\hline$H_{0}$ & rejected & rejected & rejected \\
\hline $\begin{array}{l}\text { Pearson's correlation } \\
\text { coefficient referred to } \\
\text { category } 3\end{array}$ & 0,4188 & $-0,2264$ & $-0,2436$ \\
\hline t-statistics $\left(\mathrm{t}_{3}\right)$ & 2,21 & $-1,11$ & $-1,20$ \\
\hline$H_{0}$ & $\begin{array}{l}\text { not } \\
\text { rejected }\end{array}$ & $\begin{array}{l}\text { not } \\
\text { rejected }\end{array}$ & $\begin{array}{l}\text { not } \\
\text { rejected }\end{array}$ \\
\hline $\begin{array}{l}\text { Pearson's correlation } \\
\text { coefficient referred to } \\
\text { category } 4\end{array}$ & 0,2663 & 0,1832 & 0,0092 \\
\hline t-statistics $\left(\mathrm{t}_{4}\right)$ & 1,32 & 0,89 & 0,04 \\
\hline$H_{0}$ & $\begin{array}{l}\text { not } \\
\text { rejected }\end{array}$ & $\begin{array}{l}\text { not } \\
\text { rejected }\end{array}$ & $\begin{array}{l}\text { not } \\
\text { rejected }\end{array}$ \\
\hline $\begin{array}{l}\text { Pearson's correlation } \\
\text { coefficient referred to } \\
\text { category } 5\end{array}$ & 0,2484 & 0,3051 & 0,0128 \\
\hline t-statistics $\left(\mathrm{t}_{5}\right)$ & 1,23 & 1,54 & 0,06 \\
\hline$H_{0}$ & $\begin{array}{l}\text { not } \\
\text { rejected }\end{array}$ & $\begin{array}{l}\text { not } \\
\text { rejected }\end{array}$ & $\begin{array}{l}\text { not } \\
\text { rejected }\end{array}$ \\
\hline
\end{tabular}

xi It is relatively strong measure of socioeconomic standard no matter the reactions against its potential [19], [42]. 
The relative share of category 1 proved relatively larger in the poorer countries, which still have to catch-up to meet the "physiological" needs to a sufficient degree. In addition, in regards with this category, the relationship proved negative. By increasing the GDP per capita, the weight of higher product categories grow up. The correlation is the strongest and most obviously positive, but also statistically significant, in regards with category 2 , a large part of expenditures here paid for through the redistribution mechanism of public budgets. This could be because countries with relatively higher living standards have met their prime needs to a sufficient degree, becoming allowed to increase significantly the consumption of "security products".

As to the other three product categories, $t$ statistics is lower than critical value for the test with 23 degree of freedom and $\alpha=0.005$, not leading to the rejection of the null hypothesis. However, by increasing the tolerable risk, the statistical significance of Pearson's coefficient consistently confirmed. With 23 degrees of freedom and $\alpha=$ 0.25 , for category 3 the statistical significance confirmed in all three years, for category 4 - only for 2000, and for category 5 confirmed for 2000 and 2005 (see tabl.5). With $\alpha=0.4$ a positive correlation for category 4 is confirmed in 2005 as well.

Table 5: Additional t-test of Pearson's coefficient.

\begin{tabular}{|l|l|l|l|}
\hline Years & 2000 & 2005 & 2010 \\
\hline $\begin{array}{l}\text { t-theoretical with } \\
\mathbf{2 3} \mathbf{d f} \text { and } \mathbf{\alpha}=\mathbf{0 , 2 5}\end{array}$ & 1,06 & 1,06 & 1,06 \\
\hline t-statistics (t3) & 2,21 & $-1,11$ & $-1,2$ \\
\hline H0 & Rejected & Rejected & Rejected \\
\hline t-statistics (t4) & 1,32 & 0,89 & 0,04 \\
\hline H0 & Rejected & $\begin{array}{l}\text { not } \\
\text { rejected }\end{array}$ & not rejected \\
\hline t-statistics (t5) & 1,23 & 1,54 & 0,06 \\
\hline H0 & Rejected & Rejected & not rejected \\
\hline $\begin{array}{l}\text { t-theoretical with } \\
\text { 23 df and } \mathbf{\alpha}=\mathbf{0 , 4}\end{array}$ & 0,26 & 0,26 & 0,26 \\
\hline t-statistics (t4) & 1,32 & 0,89 & 0,04 \\
\hline H0 & Rejected & Rejected & not rejected \\
\hline t-statistics (t5) & 1,23 & 1,54 & 0,06 \\
\hline H0 & Rejected & Rejected & not rejected \\
\hline
\end{tabular}

For the two product categories at the upper stages, the correlation proves statistically significant not for all observed years, specifically, it is not confirmed at all for the crisis year of 2010. No matter the fact, the results of this test are rather interesting, principally supporting my previous findings, but also providing me with arguments to confirm my third and fourth hypotheses.

The values of Pearson's coefficient in regards with the upper three categories witnessing a weak correlation by year. In particular, a positive weak relationship revealed between the socio-economic standard and product category weights, respectively, for category 3 in 2005 (0.4188), for category 5 in two of observed years ( 0.2484 in 2000 , and 0.3051 in 2005), and for category 4 only in 2000 (0.2663). As to category 3 , signs of a changing relation from positive to negative identified. As the results of $t-$ test for these categories partially proven statistically significant, at higher levels of tolerable risk, this may be because in higher categories of products the influence of non-economic factors on the consumption process increases. Further research in this direction is needed.

\section{Conclusion}

In this article, an attempt to describe human development in economic terms is under consideration. At a personal level, the product structure of consumption is a manifestation of human development degree; however, such an assessment could not tell us much about the socioeconomic conditions in a given society and the possibilities and obstacles they provide to citizens. A basic assumption for our analysis is that a more informative approach is to stem out from the viewpoint of the community at large. For this reason, I try to transform Maslow's pyramid of basic human needs into a product pyramid of total final consumption of a country (society).

I constructed a theoretical model on the base of redistribution of product classes and divisions set out in the Central product classification for statistical purposes [3], [4], by analogy with Maslow's classification of human needs. The model was tested empirically.

My first hypothesis about the hierarchy of FC product categories, which correspond to the five categories of human needs, was confirmed. The second hypothesis about a significant difference between countries (societies) in this product structure of FC was also confirmed. The third hypothesis about a positive relationship between the difference in terms of socio-economic standard and the 5-category structure of FC was also confirmed. The countries that differ in the economic standard also differ significantly in terms of the 5-categoryproduct model of FC constructed here. Less developed countries have significantly higher shares of the bottom stage of product pyramid. Only the hypothesis about the relationship between growths of economic standard and shares of product 
categories was partially confirmed, even at higher levels of acceptable risk.

The findings of this study, as well as the confirmation of the main hypotheses, give us reason to continue in the direction of a more precise examination of the relationship between product categories and the definition of the proportion. The relationship between the proportion in the product pyramid and the influence of factors of different nature such as price, technological, geographical, political deserves special attention. This aspect will be the subject of my next work in this field. For this purpose, however, a more detailed database on the product structure of FC, which is not available in the officially published use tables, is needed.

The construction of a product model of FC, which takes into account the type of human needs as an indicator of human development, has the potential for application in the input-output analysis and forecasting of the vector of final use. The study of the relationship between FC and factors external to the economy can serve to assess the external effects manifested through this component on the gross output by industry and the economy as a whole [43], [28], [12]. 
Appendix:

Table 1: Correspondence of product categories to the five categories of basic human needs

\begin{tabular}{|c|c|c|c|}
\hline \multirow[b]{2}{*}{$\begin{array}{l}\text { Human } \\
\text { needs in } \\
\text { Maslow's } \\
\text { theory }\end{array}$} & \multirow[b]{2}{*}{ Product categories } & \multicolumn{2}{|c|}{ Product codes according to $\mathrm{CPC}^{\text {xii* }}$} \\
\hline & & $\begin{array}{l}\text { Version } \\
1.1 \\
2000- \\
2005\end{array}$ & $\begin{array}{c}\text { Version } 2 . \\
2008-2010\end{array}$ \\
\hline 1 & 2 & 3 & 4 \\
\hline 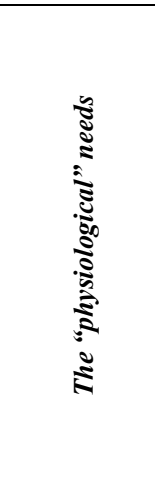 & $\begin{array}{l}\text { The "prime" products } \\
\text { Goods and services used directly to meet the physiological needs and demographic } \\
\text { reproduction. Goods and services that served indirectly to physiological needs and } \\
\text { demographic reproduction because of changes in lifestyle due to socio-economic and } \\
\text { technological shifts. } \\
\text { • Meeting directly physiological needs: } \\
\text { Food, beverages, tobacco, clothing, footwear; pharmaceuticals, water supply, electric and } \\
\text { thermal energy supply. } \\
\text { - Meeting indirectly physiological needs: } \\
\text { Real estate services, including rental of dwellings and imputed rents of owner-occupied } \\
\text { dwellings; electricity, gas, steam and air conditioning; natural water, water treatment } \\
\text { and supply services; furniture and other manufactured household goods; paper and paper } \\
\text { products; metal products, household appliances and apparatus for the population; tools } \\
\text { for personal use in everyday life and home farming, incl. various electrical appliances. }\end{array}$ & $\begin{array}{l}01,02,05 \\
10,11,14 \\
15,16 \\
17,18,19 \\
20 \\
21 \\
23 \\
24,25,26 \\
27 \\
28 \\
29,31 \\
36 \\
40 \\
41 \\
70\end{array}$ & $\begin{array}{l}\text { A01, A02, A03 } \\
\text { B } \\
\text { C10-C12 } \\
\text { C13-C15 } \\
\text { C16 } \\
\text { C17 } \\
\text { C19 } \\
\text { C20, C21, C22, C23 } \\
\text { C24 } \\
\text { C25 } \\
\text { C27, C28 } \\
\text { C31-C32 } \\
\text { D35 } \\
\text { E36 } \\
\text { L68A; L68B }\end{array}$ \\
\hline 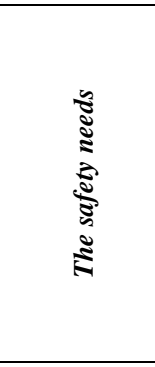 & $\begin{array}{l}\text { The "safety and security" products } \\
\text { - Goods and services for personal and collective safety and security } \\
\text { (personality, property and political rights): } \\
\text { Public administration and defense services; compulsory social security services; human } \\
\text { health services; residential care services; social work services including accommodation; } \\
\text { sewerage services; sewage sludge; waste collection, treatment and disposal services; } \\
\text { materials recovery services; remediation services and other waste management services; } \\
\text { services provided by non-profit organizations to households. } \\
\text { - Goods and services for socio-economic safety: } \\
\text { Education and training services; insurance, reinsurance and pension fund services, } \\
\text { including compulsory social security. }\end{array}$ & $\begin{array}{l}66 \\
75 \\
80 \\
85 \\
90 \\
91 \\
93 \\
95\end{array}$ & $\begin{array}{l}\text { E37-E39 } \\
\text { K65 } \\
\text { O84 } \\
\text { P85 } \\
\text { Q86, Q87-Q88 } \\
\text { S94 } \\
\text { S96, U } \\
\text { T }\end{array}$ \\
\hline 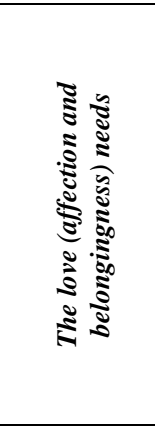 & $\begin{array}{l}\text { The "connectivity" products } \\
\text { Goods and services to needs for socio-economic integrity driven by the social dynamics, } \\
\text { technological changes and economic integrity. } \\
\text { - Serving directly: } \\
\text { Wholesale and retail trade; transport services (land transport and transport services via } \\
\text { pipelines, water transport and air transport services); motor vehicles and motorcycles; } \\
\text { postal and courier services; telecommunications services; financial services, financial } \\
\text { mediation services; legal services. } \\
\text { - Serving indirectly because of changes in lifestyle and consumer behavior: } \\
\text { Repair services of vehicles, computers, personal and household goods; employment } \\
\text { services; construction and construction works; rental and leasing services of vehicles and } \\
\text { other machinery; computers and other communication devices; services of various types } \\
\text { of expertise (not related to economic activities, but to household activities). }\end{array}$ & $\begin{array}{l}30,32,33 \\
34,35 \\
37 \\
45 \\
50,51,52 \\
60,61,62 \\
64 \\
65,67 \\
71 \\
72 \\
74\end{array}$ & $\begin{array}{l}\text { C26 } \\
\text { C29, C30 } \\
\text { F } \\
\text { C33, G45, G46, G47, S95 } \\
\text { H49, H50, H51 } \\
\text { H53, J61 } \\
\text { K64, K66 } \\
\text { N77 } \\
\text { J62-J63 } \\
\text { M69-M70, M71, M73, } \\
\text { M74-M75, N78, N80- } \\
\text { N82 }\end{array}$ \\
\hline 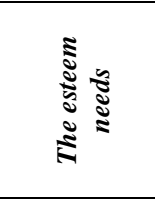 & $\begin{array}{l}\text { The "esteem" products } \\
\text { Goods and services for recreation, physical recovery, culture. } \\
\text { - Serving of mass culture and recreation (self-esteem): } \\
\text { Services of culture, sports, recreation and entertainment. } \\
\text { Other personal services; accommodation and foodservices; **warehousing and support } \\
\text { services for transportation, including services of tourist agencies. }\end{array}$ & $\begin{array}{l}55 \\
63^{* *} \\
92\end{array}$ & $\begin{array}{l}\text { I } \\
\text { H52**, N79 } \\
\text { R90-R92, R93, J59-J60 }\end{array}$ \\
\hline 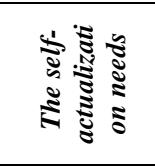 & $\begin{array}{l}\text { The "self-actualization" productc } \\
\text { Goods and services to develop intellectual potential of a community (in strictly defined } \\
\text { sense). The category is presented only by final consumption expenditures paid for by } \\
\text { governmental and non-for-profit organizations to support scientific research and } \\
\text { development, publication and reproduction of intellectual property products. }\end{array}$ & $\begin{array}{l}22 \\
73\end{array}$ & $\begin{array}{l}\text { C18, J58 } \\
\text { M72 }\end{array}$ \\
\hline
\end{tabular}

Notes: Own work. *The product classifier used by Eurostat and national statistical offices.

** Products fall into an inappropriate category because of changes in the classifier.

\footnotetext{
xii Over the 2000-2010 period, the System of National Accounts (SNA) and the European System of Accounts (ESA) used two versions of the central product classification (CPC) - respectively, Ver. 1.1 for 2000-2005 and Ver. 2 for 2008-2010.
} 
References:

[1] A. H., Maslow, A theory of human motivation. Psychological Review 50, 1943, pp. 370-396.

[2] Bolfa T. Eugen, Studies Regarding Tourism Development Perspectives in the Existing Economical and Environmental Context WSEAS Transactions on Environment and Development, pp. 197-203, Volume 15, 2019

[3] Central Product Classification. Ver. 1.1, Rev. Ed., United Nations Statistical Commission, New York, 2002. 5-8 March. https://unstats.un.org/unsd/statcom/doc02/cpc.p df (accessed August 12, 2019).

[4] Central Product Classification Ver. 2., Rev. Ed., UN, New York, 2008b.

[5] Council Regulation (EC) No 1083/2006. Official Journal of the European Union, EU 2006. L 210/25- L 210/78. 31.7. https://eurlex.europa.eu/legalcontent/EN/TXT/PDF/?uri=CELEX:32006R10 $83 \&$ from $=\mathrm{EN}$ (accessed August 14, 2019)

[6] D. Acemoglu and J. A. Robinson, Zashto natsiite se provalyat: Kude sa korenite na silata, prosperiteta I bednostta [Why Nations Fail: The origins of Power, Prosperity, and Poverty]. Trans. Zhana Tsenova, Iztok-Zapad, Sofia, 2013.

[7] Drakopoulos A. S., The implicit psychology of the theory of the rational consumer: an interpretation, Australian Economic Papers, December 1990, pp. 182-198.

[8] D. Genkova, Fondovete na Evropeyskia sayuz I ikonomicheskoto razvitie na Balgaria [The funds of the European Union and the Economic Development of Bulgaria], PhD diss., University of National and World Economy, 2013.

[9] E. Mateev, Struktura I upravlenie na ikonomicheskata sistema [The Structure and the Governance of the Economic System], Sate Publishing House "Nauka I izkustvo", 1987.

[10] E.S. Seeley, The implications of Maslow's theory of motivation for consumer behavior: a hierarchical consumption theory. Ph.D. diss., New York University, Graduate School of Business Administration, 1988.

[11] G. Katona, Rational behaviour and economic behaviour. Psychological review, vol. 60. 1953.

[12] G. Kiranchev, The invisible hands of interindustry links. Economic Alternatives, no. 2, 2011, pp. 39-44.

[13] G.L.S. Shackle, Epistemics and Economics, Cambridge University Press, 1972.
[14] H. Leibenstein, Beyond economic man, Cambridge MA: Harvard University Press, 1976.

[15] H. Simon, Theories of decision - making in economics and behavioural science, American Economic Review, vol. 49, 1959.

[16] Input-output tables, Statistics Denmark. https://www.dst.dk/en/Statistik/emner/nationalr egnskab-og-offentlige-finanser/produktivitetog-input-output/input-output-tabeller (accessed November 18, 2017)

[17] J. Elster, Ulysses and the Sirens: studies in rationality and irrationality, Cambridge University Press, Cambridge, 1979.

[18] J. March, Bounded rationality, ambiguity and the engineering of choice, Bell Journal of Economics, vol. 9, 1978.

[19] J. Stieglitz, A. Sen and F. J. Jean-Paul, Report by the Commission on the measurement of economic performance and social progress, 2009.

https://ec.europa.eu/eurostat/documents/118025 /118123/Fitoussi+Commission+report (accessed August 12, 2019).

[20] K. Gatev, Metodi za analiz na strukturi I strukturni efekti [Methods for analyzing structures and structural effects], University Press "Stopanstvo", Sofia, 2007.

[21] L. Boland. On the futility of criticizing the Neoclassical Maximization Hypothesis, American Economic review, vol. 71, 1981.

[22] L. Robbins, An essay in the nature and significance of Economic Science, Macmillan, London, 1932.

[23] M. E. Porter, Konkurentnoto predimstvo na natsiite [The Competitive Advantage of Nations]. Trans. Kristina Andreeva. Publishing House Klasika I Stil, Sofia, 2004.

[24] M. Friedman, Essay in Positive Economics, University of Chicago Press. 1953.

[25] M. Voynarenko, V. Dzhedzhula and I. Yepifanova, Modeling of the Process of Personnel Motivation for Innovation Activity, WSEAS Transactions on Business and Economics, Vol. 17, 2020, pp. 467-477.

[26] P. Earl, The economic imagination. Brighton: Wheatsheaf Books. 1983.

[27] P. Samuelson, Foundations of economic analysis, Harvard University Press, 1947.

[28] R. E. Miller and P. D. Blair, Input-Output Analysis: foundations and extensions. $2^{\text {nd }} \mathrm{ed}$. NY: Cambridge University Press, 2009.

[29] R. Heiner, The origin of predictable behaviour, American Economic Review, vol. 73, 1983. 
[30] Supply and use tables. Central Bureao voor de Statistiek [NL]. https://www.cbs.nl/en-gb (accessed November 25, 2017)

[31] Supply and use tables. Instituto Nacional de Estadistica [ES].

https://www.ine.es/dyngs/INEbase/en/categoria .htm?c=Estadistica_P\&cid=1254735576581 (accessed November 25, 2017)

[32] Supply and use tables. Office for National Statistics [GB].

https://www.ons.gov.uk/economy/nationalacco unts/supplyandusetables (accessed December 6, 2017)

[33] Supply, use and input-output tables. Eurostat database.

https://ec.europa.eu/eurostat/data/database (accessed July 30, 2017)

[34] S. Winter, Concepts of rationality in behavioural theory. Institute of Public Policy Studies, Discussion Paper, University of Michigan. 1969.

[35] System of National Accounts. 2009. Ver. 2008. New York: UN, WB, IMF, OECD, EC. https://unstats.un.org/unsd/nationalaccount/doc s/SNA2008.pdf (accessed August 12, 2019)

[36] Th. Veblen, Teoria na bezdelnata klasa [The theory of the leisure class: An economic study of institutions]. Trans. Rossen Lyutskanov, Publishing house "Iztok-Zapad", Sofia, 2016.

[37] United Nations Development Program. 2010. Human Development Report 2010: The Real Wealth of Nations; Pathways of Human Development. $20^{\text {th }}$ Anniversary Ed. UN.NY.

[38] V. Baleva, Productat: Marketingovi strategii I pilitiki [The Product: Marketing Strategies and Policies], University Press "Stopanstvo", Sofia, 2007.

[39] V. Baleva and P. Ivanov, Sistema na natsionalnite smetki [The System of National Accounts], University Press "Stopanstvo". Sofia 2003.

[40] V. Manov, Prognozirane I planirane razvitieto I funktsioniraneto na ikonomicheskite sistemi [Forecasting and Planning the Operations and the Development of Economic Systems], University Press "Stopanstvo", Sofia, 2001.

[41] V. Pareto, Manual of political economy, Transl. by A. Schwier, London: Macmillan, 1971.

[42] V. Petrov, P. Angelova, and K. Slaveva, Zhizneniat standart na naselenieto statisticheski analiz [The Living Standard of Population - a Statistical Analysis], Library "Stopanski sviat", n.s., 90, Dimitar A. Tsenov Academy of Economics. Svishtov, 2007.
[43] W. Leontief, Input-Output Economics, NY: Oxford University Press. 1966.

[44] World Input-Output Database 2016. http://www.wiod.org/release16 (accessed July $23,2019)$.

\section{Contribution of individual authors to the creation of a scientific article (ghostwriting policy)}

No co-authors.

\section{Sources of funding for research presented in a scientific article or scientific article itself}

Research Project NID NI-15/2017, under the Research Program of the University of National and World Economy 2017.

\section{Creative Commons Attribution License 4.0 (Attribution 4.0 International, CC BY 4.0)}

This article is published under the terms of the Creative Commons Attribution License 4.0 https://creativecommons.org/licenses/by/4.0/deed.en US 